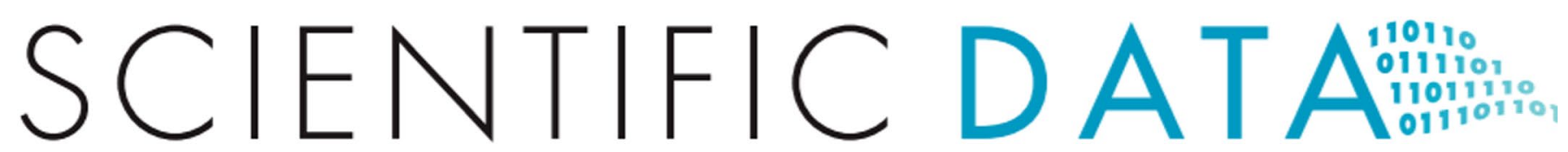

Check for updates

\title{
Author Correction: High-resolution, large-scale laboratory measurements of a sandy beach and dynamic cobble berm revetment
}

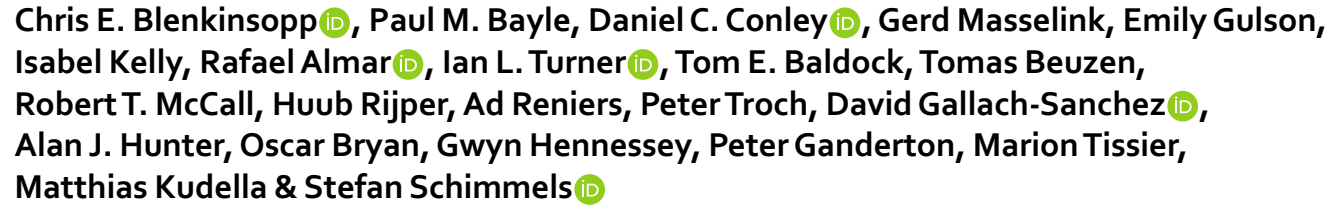

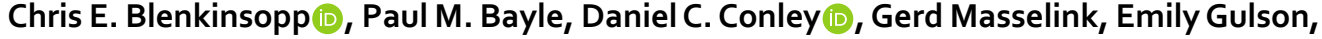

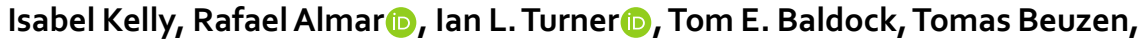
Robert T. McCall, Huub Rijper, Ad Reniers, Peter Troch, David Gallach-Sanchez $\mathbb{D}$, Alan J. Hunter, Oscar Bryan, Gwyn Hennessey, Peter Ganderton, Marion Tissier, Matthias Kudella \& Stefan Schimmels $\mathbb{B}$

Correction to: Scientific Data https://doi.org/10.1038/s41597-021-00805-1, published online 20 January 2021

The original version of this Data Descriptor contained errors in the author affiliations. Peter Troch was incorrectly associated with DEME Group and the Department of Civil Engineering, Ghent University was inadvertently omitted. This has now been corrected in both the PDF and HTML versions of the Data Descriptor.

(c) Open Access This article is licensed under a Creative Commons Attribution 4.0 International C. License, which permits use, sharing, adaptation, distribution and reproduction in any medium or format, as long as you give appropriate credit to the original author(s) and the source, provide a link to the Creative Commons license, and indicate if changes were made. The images or other third party material in this article are included in the article's Creative Commons license, unless indicated otherwise in a credit line to the material. If material is not included in the article's Creative Commons license and your intended use is not permitted by statutory regulation or exceeds the permitted use, you will need to obtain permission directly from the copyright holder. To view a copy of this license, visit http://creativecommons.org/licenses/by/4.0/.

(C) The Author(s) 2021 